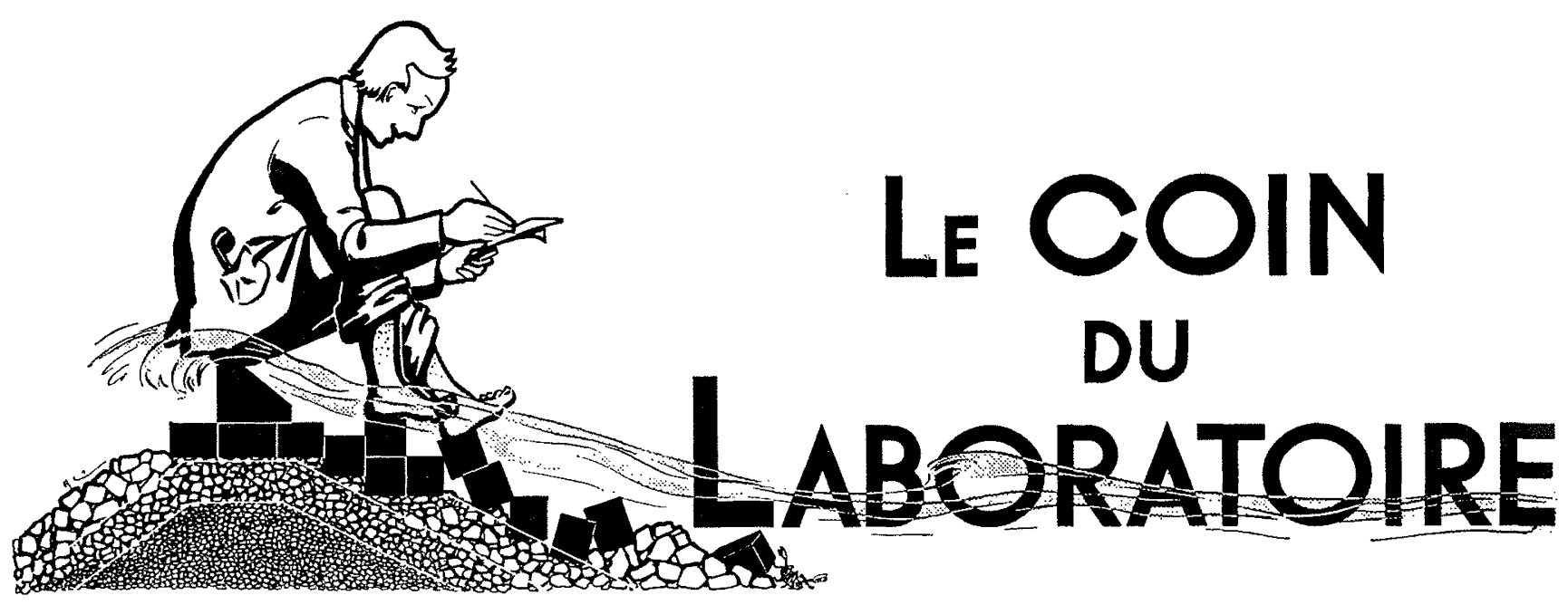

LABORATORY PRACTICE

\title{
Essais effectués sur un amortisseur de houle de modèle réduit
}

\author{
Wave absorber in small-scale tests with waves
}

Description d'un amortisseur de houle destine à empêcher ou à limiter la réflexion de la houle dans les modèles réduits comportunt des briselames.

L'étude sur modèles réduits de la nature de la houle exige généralement l'installation, aux extrémités du canal à houle ou aux lişnes de délimitation d'un modèle de port, de dispositifs réduisant la réflexion de la houle pratiquement à zéro. Si l'on permet à la houle de se réfléchir, il naîtra des perturbations ne correspondant pas à la réalité.
Description of a wave absorber intended to eliminate or reduce wave reflection in scale models containing break waters.

When making small-scale tests with waves, some arrangements are usually necessary at the end of the testing flume or within the boundaries of the model harbour to prevent wave reflexion or reduce it to the smallest possible extent. If the waves are allowed to rebound, disturbances which have no parallel in reality interfere with the tests. 
Ce problème se pose surtout lorsqu'il s'agit d'essais sur modèles réduits effectués sur des brise-lames placés dans un canal à houle. En modelant le profil du côté large d'un briselames, il faut tenir compte de certaines conditions de réflexion, qui affectent les caractéristiques de la hoüle. Pour pouvoir déterminer d'une manière simple ces conditions de réflexion, il faut connaître les caractéristiques de la houle primitive, c'est-à-dire de la houle qui se serait produite s'il n'y avait eu ni brise-lames ni réflexion dans le canal.

Afin de pouvoir étudier les caractéristiques de la houle non influencée par des réflexions, le Laboratoire d'Hydraulique de l'Ecole Polytechnique Supérieure de Chalmers a mis au point un amortisseur de houle qui semble supérieur aux amortisseurs couramment employés, tels que les talus de pierre de pente douce, la fibre de bois enrobée de treillage ou du treillage plié et pressé. Les essais effectués sur l'amortisseur ont été réalisés parallèlement avec des essais sur des modèles réduits de brise-lames, dans un canal de $26 \mathrm{~m}$ de longueur, $0,93 \mathrm{~m}$ de largeur et $0,82 \mathrm{~m}$ de profondeur.

La figure 1 représenle le profil de l'amortisseur de houle.
The problem is of particular importance during small-scale tests of breakwaters in a wave flume. The windward side of every breakwater has its own individual reflexion type which influences the characteristics of the waves. In order to determine in a simple way the reflexion type it is necessary to know the characteristics of the original waves, that is to say, the characteristics on the waves formed if there were no model breakwater in the test flume and if no reflexion occurred.

In order to determine the characteristics of waves unaffected by reflexion, a wave absorber, which seems to be more effective than the usual types-rockfill slopes, wood-wool in wire netting or balls of wire netting-has been constructed at the Laboratory of Hydraulies of Chalmers' University of Technology. The wave absorber was tested in conjunction with small-scale tests of breakwaters in a flume $26 \mathrm{~m}$ long, $0.93 \mathrm{~m}$ wide and $0.82 \mathrm{~m}$ deep.

Fig. 1 shows a cross section of the wave absorber.

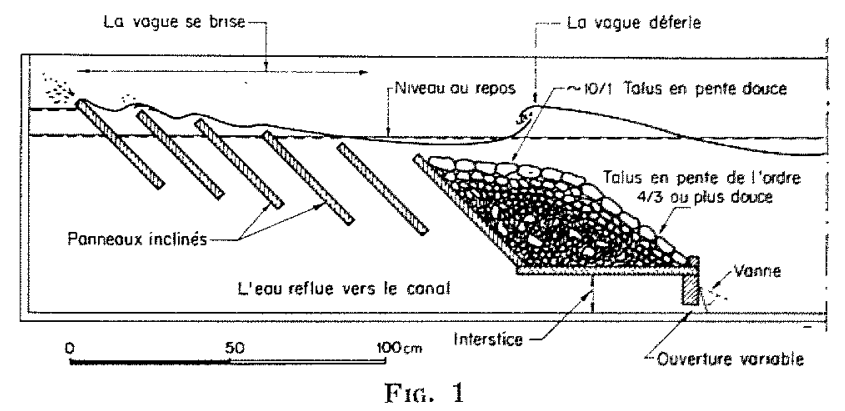

Proful de l'amortisscur à l'extrémité da canat de houte.

Cross section of wave absorber at the end of the flume.

L'amorlisseur de houle consiste essentiellement en une série de panneaux inclinés dont le bord supérieur affleure ou dépasse légèrement le niveau d'eau calme et un talus de macadam en pente douce de profil bombé, placé sous le niveau d'eau calme à une hauteur laissant entre sa partie inférieure et le fond du canal un passage dont l'ouverture est variable.

L'amortisseur de houle fonctionne de la manière suivante : la houle incidente déferle sur le lalus en pente douce, ce qui donne pratiquement aux masses d'eau une direction de mouvement unique vers la paroi verticale de l'extrémité arric̀re du canal. Chaque vague se brise ensuite sur le bord supérieur des panncaux inclinés, la masse d'eau passe entre les panneaux et rellue
In principle the wave absorber consists of a number of sloping plates, the top edges of which are above still water level, a gentle broken slope of macadam below still water level and a space with a variable opening between the bottom of the flume and the macadam slope.

The wave absorber works in the following way. The incoming waves are made to break on the gentle part of the stone slope, as a result of which the masses of water in the waves move in a practically identical direction towards the vertical wall at the end of the flume. After that every wave is broken up against the top edges of the sloping plates, the masses of waler are 

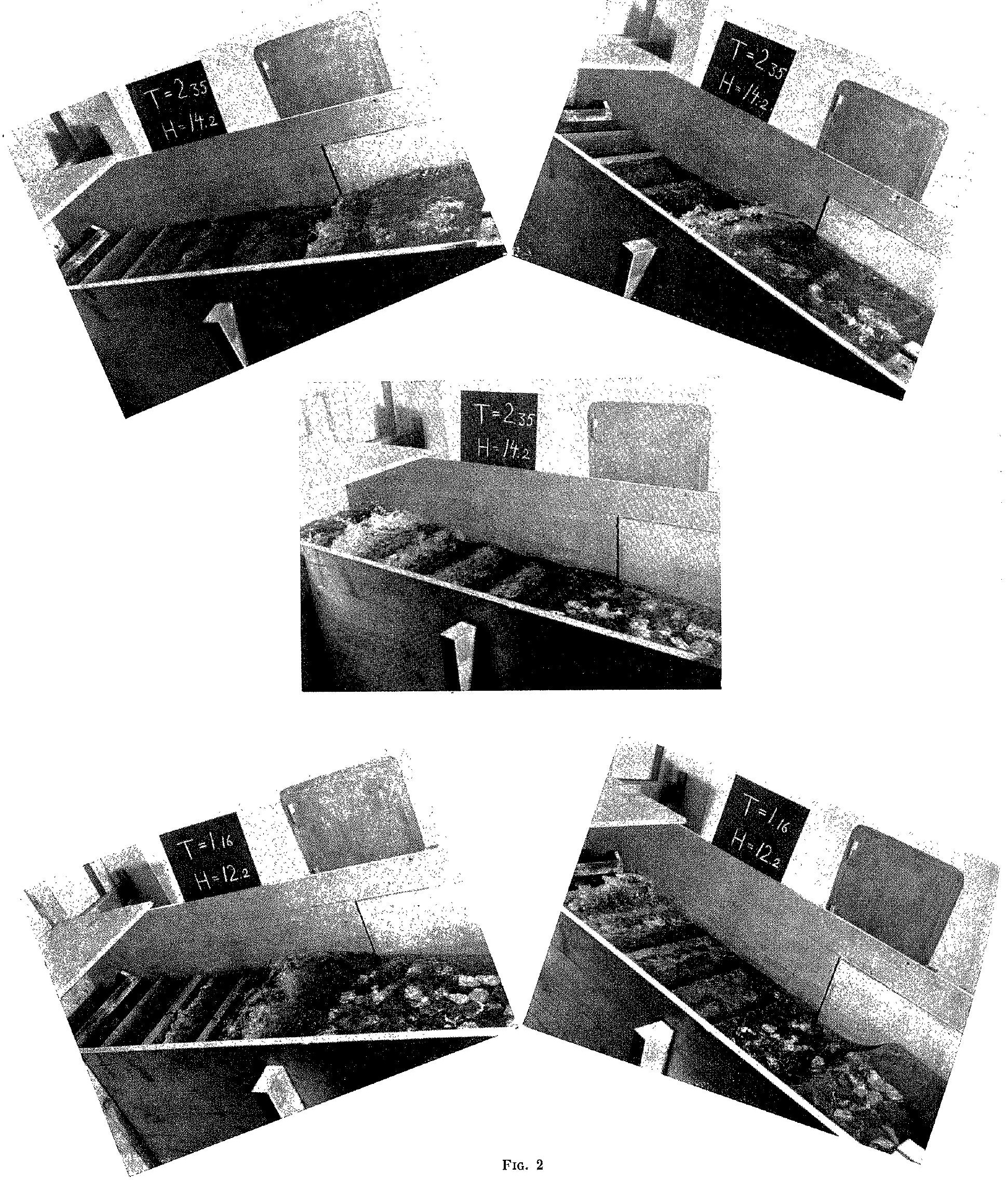

L'amortisseur montrant des phases successives de houle de deux périodes différentes. Some different phases of the twave motion at the absorber. Two wave periods. 
vers le canal, par le passage ménagé entre le talus et le fond du canal, et sort ensuite dans le canal par une vanne. La masse d'eau qui reflue dans le canal regagne celui-ci sans causer de perturbations notables à la houle incidente (1).

L'intervalle entre les surfaces des panneaux a été fixé à environ la moitié de l'amplitude maximum pouvant être réalisée dans le canal, soit $20 \mathrm{~cm}$. Les trois panneaux arrière sont un peu plus rapprochés les uns des autres. Le bord supérieur du premier panneau avant se trouve immergé de façon à laisser, entre lui et le ni- split up and return between the plates and under the macadam slope and finally out through a gate into the flume. The returning water reaches the flume without seriously disturbing the incoming waves (1).

The space between the plates was chosen at about half the maximum wave height $-20 \mathrm{~cm}-$ that could be produced in the flume. The distance between the three rear plates was somewhat less. The top edge of the foremost plate was placed a quarter of the maximum wave

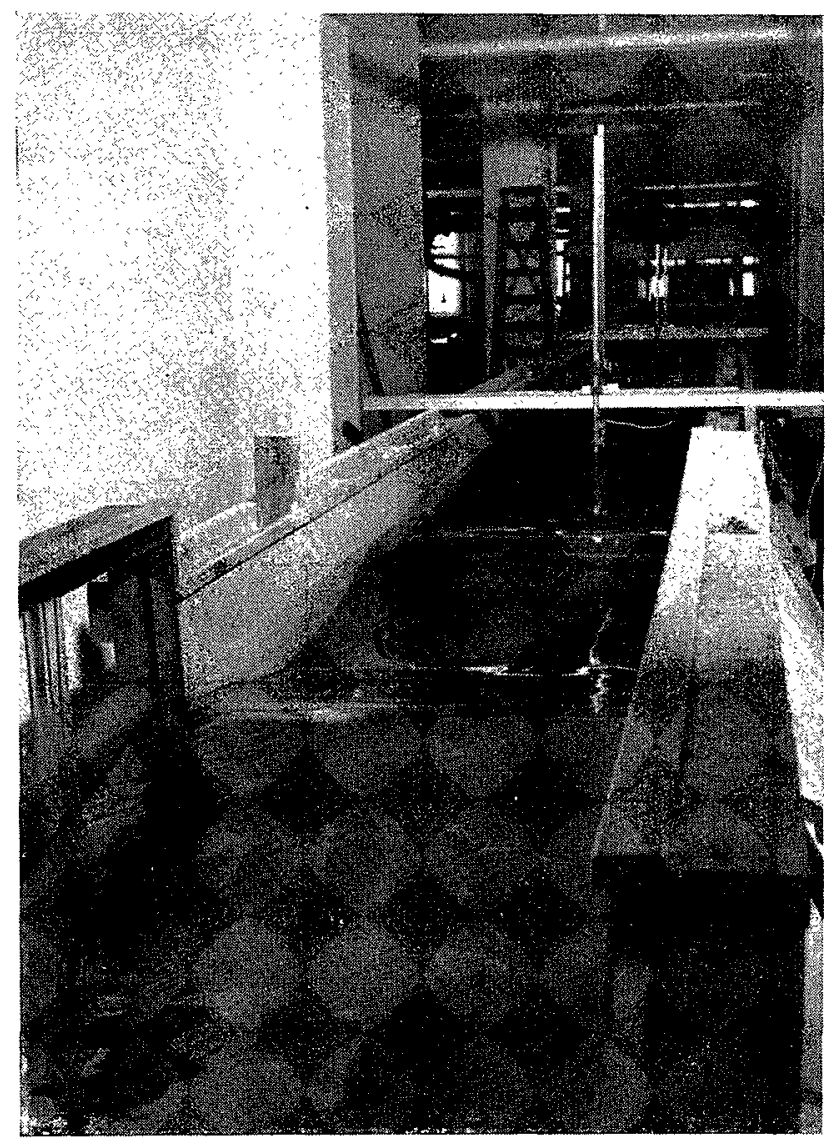

FIG. 3

Houle typique produite dans le canal.

Typical waves produced in the channel

veau d'eau calme, une distance correspondant au quart de l'amplitude maximum $(20 \mathrm{~cm})$, tandis que le bord supérieur du dernier panneau arrière émerge du double de cette distance de la surface d'eau calme. Les bords supérieurs des panneaux intermédiaires forment une ligne montante reliant les bords supérieurs des panneaux avant et arrière. La hauteur de l'intervalle entre le talus

(1) Le mouvement circulaire ou elliptique des particules de houle est affecté par les masses d'eau sortantes seulement sur une distance approximative d'une longueur d'onde devant l'ouvrage. height below still water level, and the top edge of the back plate half the maximum wave height above still water level. The heights of the top edges of the interjacent plates were evenly distributed between the first and the last plates. The height of the space under the stone slope was chosen to restrict the return flow of water so that the height of the water between and

(1) The circular or elliptical particle orbits of the waves are influenced by the escaping water for a distance of about one wave length in front of the wave absorber. 
et le fond du canal a été choisie de façon à ne pas laisser passer une quantité d'eau trop grande, afin que le niveau d'eau entre et derrière les panneaux reste toujours plus élevé que le niveau d'eau calme. La vanne en tôle placée à l'orifice avant de cet intervalle empêche l'eau de retourner dans l'amortisseur, lorsque des crêtes de vagues passent sur le talus. Au moment du passage d'une crête de vague, la vanne a son ouverture minimum, et lorsqu'un creux de vague passe, elle a son ouverture maximum. Le talus est placé, suivant l'amplitude de la houle, à la profondeur qui donne des brisants prononcés.

L'amortisseur a été soumis à des essais effectués avec des amplitudes allant de 4 à $20 \mathrm{~cm}$ et des périodes de 1,15 à $2,35 \mathrm{~s}$, sans autre modification que le relèvement ou l'abaissement du talus. Comme, en plus de l'amortisseur de houle décrit ci-dessus, le canal d'essai est équipé d'un filtre à houle construit suivant les mêmes principes que celui décrit par $F$. Bresex dans la Honille Blanche de mai-juin 1948, page 276, on obtient entre le filtre et l'amortisseur une houle très uniforme et régulière. L'amplitude varie peu le long du canal (environ $10 \%$ de l'amplitude, $\min .5 \%, \max .15 \%)$, et on peut choisir la période que l'on désire.

Lorsque le batteur est arrêté, la houle se calme vite dans le canal. La dernière vague ayant déferlé sur l'amortisseur, il ne reste dans le canal qu'une houle insignifiante ayant une amplitude maximum de $3 \mathrm{~cm}$. En moins de 1 à 3 minutes, le canal redevient tout à fait calme.

Les photos de la figure 2 représentent l'amortisseur en fonctionnement et la figure 3 donne un exemple de la houle produite dans le canal.

$$
\begin{gathered}
\text { P.-A. Hedar, } \\
\text { Licencié ès sciences, } \\
\text { Ecole Polytechnique Supérieure } \\
\text { de Chalmers, } \\
\text { à Göteborg, Suède }
\end{gathered}
$$

behind the plates was constantly above still water level.

The gate at the front edge of the opening prevented the water from flowing "backwards" in the wave absorber when the crests of the incoming waves passed over the stone slope. When the wave crest passed, the gate opening was smallest, and when the trough of the wave passed, the opening was greatest. The stone slope was, for the different wave heights, placed at the depth which caused the waves to break completely

The wave absorber was tested for wave heights varying from $4 \mathrm{~cm}$ to $20 \mathrm{~cm}$ with periods of 1.15 to 2.35 seconds with no other adjustment than the lifting or lowering of the gentle macadam slope. When the testing flume was fitted with the wave absorber described above and a wave filter constructed according to the principles laid down by F. Biesel in la Houille Blanche, MayJune 1948, p. 276, very even and in character identical waves were obtained between the filter and the wave absorber. The variation in wave heights was small (about $10 \%$ of the wave height; $\min .5 \%$, max. $15 \%$ ), and any wave period could be used.

When the wave generator was stopped, the waves in the flume soon died down. After the last wave had reached the wave absorber, only a slight swell, with a maximum of $3 \mathrm{~cm}$ amplitude, remained. After one to three minutes the water in the flume was quite still.

The photographs (fig. 2) show the wave absorber in function and figure 3 gives an example of waves in the flume.

$$
\begin{gathered}
\text { P.-A. HLDAR, } \\
\text { Chulmers' University of Technolog!, } \\
\text { Göteborg, Sweden }
\end{gathered}
$$

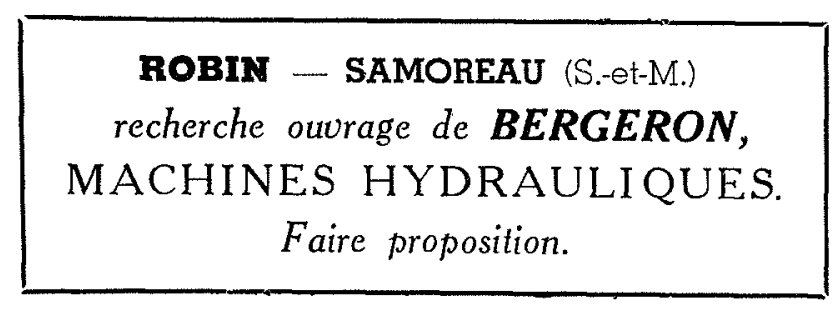

